(2) Open Access Full Text Article

\title{
Swollen lymph nodes may not be clinical manifestations of chronic myeloid leukemia: case report and revision of literature
}

This article was published in the following Dove Press journal:

Therapeutics and Clinical Risk Management

5 September 2017

Number of times this article has been viewed

\section{Zhihe Liu' \\ Siyun $\mathrm{Li}^{2}$ \\ Ou Bai}

'Department of Hematology, The First Hospital of Jilin University, Changchun, ${ }^{2}$ Department of Pediatrics, Women and Children's hospital of Qingdao university, Qingdao, People's Republic of China
Correspondence: Ou Bai

Department of Hematology, First Hospital of Jilin University, No 7 I Xinmin Street, Chaoyang district, Changchun, People's Republic of China Tel +86 43I 88782054

Fax +8643188783373

Email oubail6@l63.com
Abstract: We present here the case of a 33-year-old Chinese female patient with synchronous double primary malignant tumors (chronic myeloid leukemia [CML] and classic Hodgkin lymphoma). This patient was admitted to our hospital because of bilateral cervical lymph node enlargement and recurrent fever for 2 weeks. The complete blood cell count revealed white blood cell counts of $18.2 \times 10^{9} / \mathrm{L}$, hemoglobin of $9.6 \mathrm{~g} / \mathrm{dL}$, and platelet counts of $1,547 \times 10^{9} / \mathrm{L}$. Chromosome karyotype analysis demonstrated that $\mathrm{t}(9 ; 22)(\mathrm{q} 34 ; \mathrm{q} 11)$ was positive in all 20 cells examined. Reverse transcription polymerase chain reaction showed that the ratio of $B C R / A B L 1$ to $A B L$ was $45.3 \%$. This patient was diagnosed with CML. After definite diagnosis, this patient regularly received imatinib therapy. Three months later, although complete blood count was normal, swollen lymph nodes further increased. Swollen lymph node biopsy was performed to evaluate the nature of these swollen lymph nodes, and results displayed that Hodgkin and Reed-Sternberg cells, CD30, CD15, and Epstein-Barr virus-encoded RNA was positive. In conclusion, this patient was diagnosed with synchronous double primary malignant tumors. This case report suggests that swollen lymph nodes may be due to lymphoma, rather than as a clinical manifestation of CML.

Keywords: imatinib, lymphoma, $B C R / A B L 1$, fluorescence in situ hybridization

\section{Introduction}

Chronic myeloid leukemia (CML) is a myeloproliferative neoplasm that is defined by the presence of Philadelphia chromosome and/or the chimeric gene $B C R / A B L 1 .^{1}$ The $\mathrm{t}(9 ; 22)(\mathrm{q} 34 ; \mathrm{q} 11)$ translocation is present in $95 \%$ of cases with CML, and this gives rise to the $B C R / A B L 1$ gene. ${ }^{2}$ The development of CML is a multiple-step process initiated by significantly proliferation of myeloid cells. ${ }^{3}$ According to the criterion of National Comprehensive Cancer Network for CML, it is classified into chronic phase (CML-CP), accelerated phase, and blast phase. ${ }^{4}$ It is reported that approximately $3 \%-7.9 \% \mathrm{CML}$ patients in blast phase may suffer from extramedullary recurrence, and this event may occur or precede concurrently with CML. ${ }^{1}$ Lymph nodes, the central or peripheral nervous system, and the bone marrow are common extramedullary sites. ${ }^{5}$ Although tumor cells in extramedullary sites are all derived from a clone of CML, it is very difficult to distinguish between extramedullary recurrence of CML and true de novo lymphoma based on morphology and clinical features alone.

In this study, we present the case of a CML-CP patient with swollen lymph node, evaluating the nature of swollen lymph node by immunohistochemistry technology and fluorescence in situ hybridization (FISH) on formalin-fixed and 
paraffin-embedded lymph node biopsy tissue, and the results indicated that the nature of swollen lymph nodes was Hodgkin lymphoma (HL), rather than extramedullary recurrence of CML.

\section{Case report}

Written informed consent was obtained from the patient's next of kin for publication of this case report and the associated images. A 33-year-old woman was admitted to our hospital because of bilateral cervical lymph node enlargement and recurrent fever for 2 weeks. On admission, the patient presented with white blood cell count of $18.2 \times 10^{9} / \mathrm{L}$, hemoglobin of $9.6 \mathrm{~g} / \mathrm{dL}$, and platelet counts of $1,547 \times 10^{9} / \mathrm{L}$. Peripheral blood smear revealed $79 \%$ neutrophils, $2 \%$ eosinophils, $7 \%$ basophils, $4 \%$ monocytes, and $8 \%$ lymphocytes. Bone marrow smear demonstrated $1 \%$ myeloblasts, $74.5 \%$ neutrophils, $5.5 \%$ eosinophils, $1 \%$ basophils, $0.5 \%$ lymphocytes, $3 \%$ plasmocytes, and $14.5 \%$ erythrocytes. Cytogenetic analysis was performed by conventional technique with G-banding, and results showed that $\mathrm{t}(9 ; 22)(\mathrm{q} 34 ; \mathrm{q} 11)$ was positive in all 20 analyzed mitoses. Reverse transcriptase polymerase chain reaction (RT-PCR) displayed that the ratio of $B C R / A B L 1$ to $A B L$ was $45.3 \%$. Physical examination showed that spleen was $6.5 \mathrm{~cm}$ below the costal margin. These data allowed us to make the diagnosis of CML in chronic phase.

After definite diagnosis, this patient regularly received imatinib therapy. Three months later after therapy, complete blood count was normal; however, swollen lymph nodes further increased. Therefore, we considered that swollen lymph nodes may not be clinical manifestations of CML. For the purpose of evaluating the nature of swollen lymph nodes, lymph node biopsy was performed. Hodgkin and Reed-Sternberg cells were seen in this swollen lymph node biopsy section, and immunohistochemical staining showed that lymphoma cells were positive for CD30, CD15, EMA, and MUM-1 and negative for LCA, MPO, CD117, CD68, CD20, CD3, and TdT; Epstein-Barr virus-encoded RNA was positive for lymphoma cells and was confirmed by in situ hybridization (Figure 1). FISH analysis using $B C R$ and $A B L$ cosmid probes showed that there were no $B C R / A B L 1$ fusion genes in lymph node biopsy section (Figure 2). Based on the abovementioned results, the patient was diagnosed as having classic HL.

This patient was finally diagnosed with synchronous double primary malignant tumors (CML and HL), and then she received imatinib combined with doxorubicin, bleomycin, vinblastine, and dacarbazine therapy.
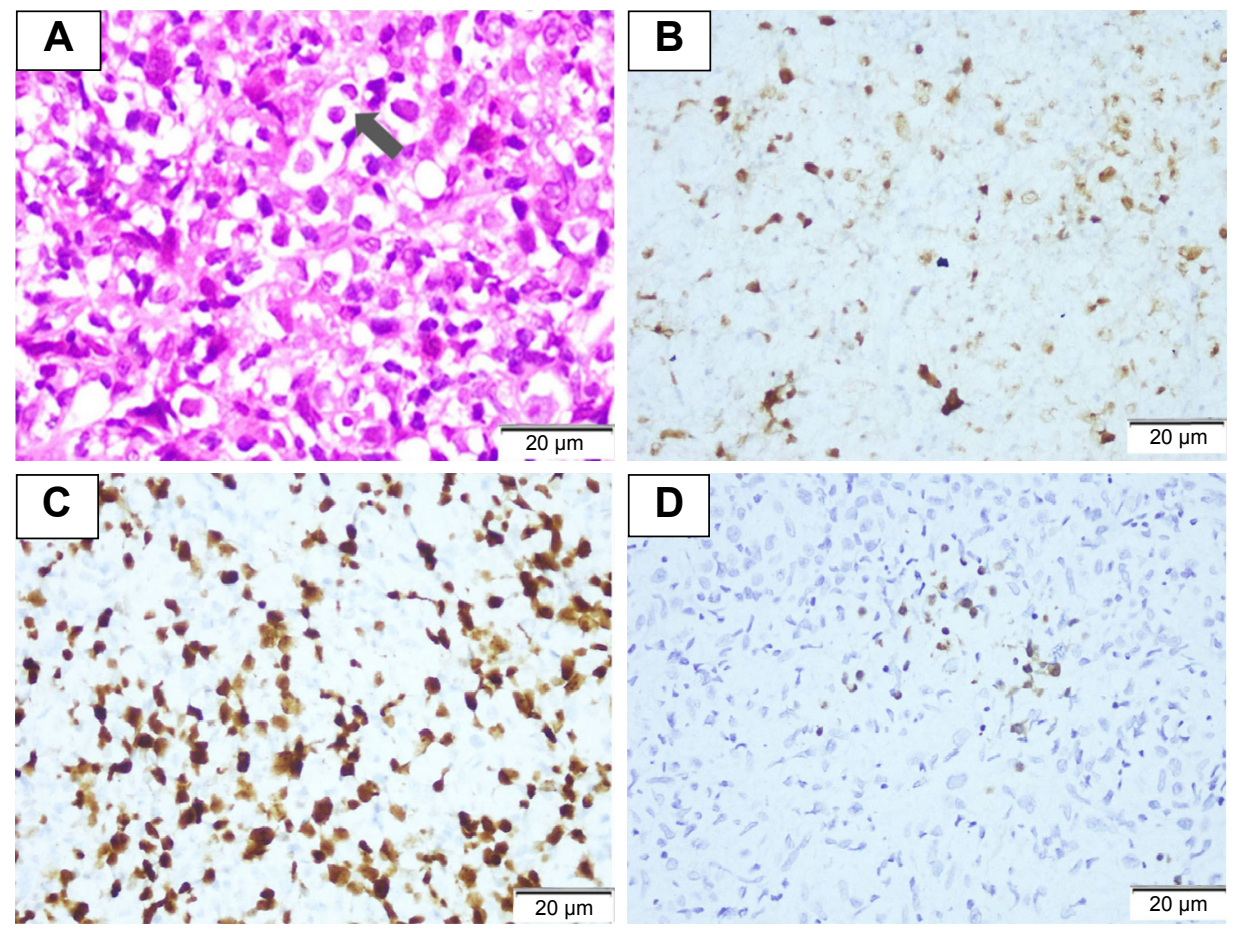

Figure I The results of swollen lymph node biopsy section. (A) Characteristic HRS cells exist in a mixed background of small lymphocytes, the arrow shows HRS cell $(\times 1,000)$. (B) CD30 positive for lymphoma cells $(\times 200)$. (C) MUM-I positive for lymphoma cells $(\times 200)$. (D) EBER was positive for lymphoma cells and was confirmed by in situ hybridization $(\times 200)$.

Abbreviations: EBER, Epstein-Barr virus-encoded RNA; HRS cell, Hodgkin and Reed-Sternberg cell. 


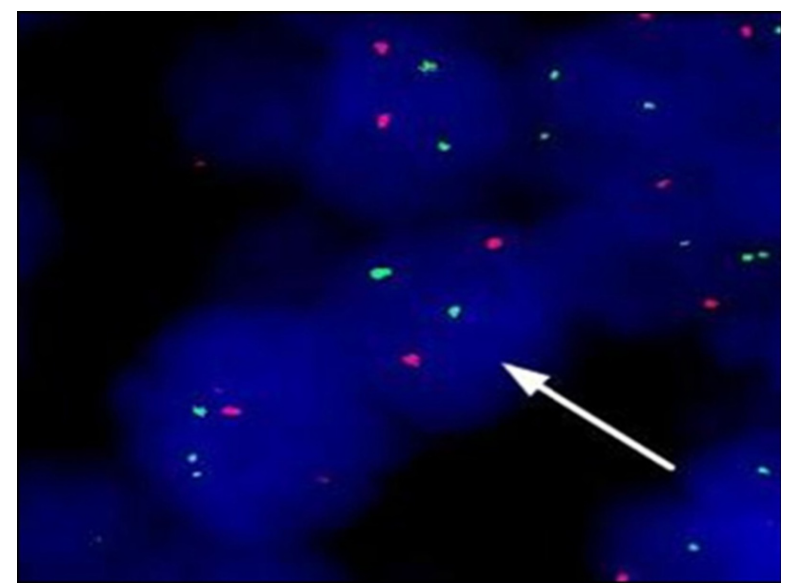

Figure $\mathbf{2}$ The result of $B C L / A B L I$ fusion gene in swollen lymph node biopsy by FISH (arrow displays that lymphoma cells without $B C R / A B L I$ fusion genes).

Abbreviation: $\mathrm{FISH}$, fluorescence in situ hybridization.

Unfortunately, the patient passed away after CML progression to acute leukemia.

\section{Discussion}

Extramedullary neoplasm is regarded as an early sign of the recurrence in CML patients. It is reported that the incidence of extramedullary neoplasm in CML patients ranges from $4 \%$ to $7.9 \% .^{3,6}$ In these studies, the frequency of lymph node swelling was as high as 50\% in CML patients with extramedullary neoplasm. Out of these CML patients with extramedullary neoplasm, $37.5 \%-50.0 \%$ cases are in the hematological chronic phase.

As far as we know, there are very few articles on CML-CP patients with extramedullary neoplasm. Kobayashi et $\mathrm{al}^{7}$ reported a case of CML-CP patient with lymph node swelling, which represented extramedullary involvement composed of cells at different stages of maturation. Kumar et $\mathrm{al}^{8}$ provided a case of CML-CP patient with multiple skin chloromas in 2013. Ganessan et $\mathrm{al}^{9}$ presented a unique case of childhood CML with extramedullary biphenotypic blast crisis (myeloid/T-cell type) at initial presentation with bone marrow remaining in chronic phase. Panikar et $\mathrm{al}^{10}$ provided a rare case with concurrent CML and tuberculous lymphadenitis. In 2004, Sakakura et $\mathrm{al}^{11}$ reported a 59-year-old man with CML in chronic phase who presented with a large abdominal tumor, and the results of abdominal tumor biopsy indicated that it was an extramedullary hematopoietic tumor of CML origin. In other articles, an intra-atrial mass, skin and pericardial effusion, and the endometrium were also seen in CML-CP patients with extramedullary involvement. ${ }^{12-14}$ Different from these rare reports mentioned, we presented herein the case of a CML-CP patient with lymph node swelling, and based on the results of morphology, immunohistochemistry, and FISH in lymph node biopsy section, the nature of swollen lymph nodes was confirmed to be de novo lymphoma, rather than clinical manifestations of CML.

Lymphoma coexisting with CML is a rare disease entity. Martoïa et $\mathrm{al}^{15}$ reported the case of a female CML patient developing a malignant follicular lymphoma. Rodler et $\mathrm{al}^{16}$ described the case of a CML patient developing mantle cell lymphoma after 3 years of imatinib therapy. According to our clinical experience on multiple primary malignant tumors, we considered that environmental exposures, specific chemotherapy drugs, radiotherapy, and genetic instability may be associated with the pathogenesis of multiple primary malignant tumors. ${ }^{17}$ But the etiology of this rare disease entity remains unclear to date.

Currently, it is still very difficult to make a definite diagnosis between extramedullary tumors of CML and true de novo lymphoma based on morphology and clinical features alone. Lymphoma is rare in CML patients and is easy to be misdiagnosed as an extramedullary transformation. For patients with synchronous double primary malignant tumors, like CML and HL, conventional cytogenetic or RT-PCR cannot clarify the nature of extramedullary neoplasm. ${ }^{16}$ Therefore, a complex investigation including conventional cytogenetic analysis, immunohistochemistry, FISH, and RT-PCR is necessary for making a definite diagnosis.

\section{Conclusion}

Given the results of morphology, immunohistochemistry, FISH, and RT-PCR, this patient was finally diagnosed with synchronous double primary malignant tumors, rather than extramedullary transformation of CML. This case strongly reminds us that we should distinguish between extramedullary transformation of CML and true de novo lymphoma as soon as possible, so as to avoid misdiagnosis.

\section{Disclosure}

The authors report no conflicts of interest in this work.

\section{References}

1. Yashima-Abo A, Satoh T, Abo T, et al. Distinguishing between proliferating nodal lymphoid blasts in chronic myelogenous leukemia and non-Hodgkin lymphoma: Report of three cases and detection of a bcr/abl fusion signal by single-cell analysis. Pathol Int. 2005;55(5):273-279.

2. Quintás-Cardama A, Cortes J. Molecular biology of bcr-abl1-positive chronic myeloid leukemia. Blood. 2009;113(8):1619-1630.

3. Inverardi D, Lazzarino M, Morra $\mathrm{E}$, et al. Extramedullary disease in $\mathrm{Ph}$ '-positive chronic myelogenous leukemia: frequency, clinical features and prognostic significance. Haematologica. 1990;75(2):146-148.

4. O'Brien S, Radich JP, Abboud CN, et al. Chronic myelogenous leukemia, version 1. 2015. J Natl Compr Canc Netw. 2014;12(11):1590-1610. 
5. Ichinohasama R, Miura I, Takahashi N, et al. Ph-negative non-Hodgkin's lymphoma occurring in chronic phase of Ph-positive chronic myelogenous leukemia is defined as a genetically different neoplasm from extramedullary localized blast crisis: report of two cases and review of the literature. Leukemia. 2000;14(1):169-182.

6. Kantarjian HM, Keating MJ, Talpaz M, et al. Chronic myelogenous leukemia in blast crisis: analysis of 242 patients. Am JMed. 1987;83(3): 445-454.

7. Kobayashi Y, Tanaka T, Kawata E, et al. Chronic myelogenous leukemia in the chronic phase with lymph node swelling which represented extramedullary involvement composed of cells at different stages of maturation. Rinsho Byori. 2011;59(4):360-363.

8. Kumar V, Jain N, Chaudhary SC, et al. Multiple skin chloromas: a rare presentation of chronic myelogenous leukaemia in chronic stable phase. BMJ Case Reports. 2013;2013:bcr2013008626.

9. Ganessan K, Goel R, Kumar K, et al. Biphenotypic extramedullary blast crisis as a presenting manifestation of Philadelphia chromosome-positive CML in a child. Pediatr Hematol Oncol. 2007;24(3):195-198.

10. Panikar N, Sikka M, Singh N. Concurrent chronic myelogenous leukemia and tuberculous lymphadenitis: a case report. Acta Cytol. 2005; 49(6):650-652.
11. Sakakura M, Ohishi K, Nomura K, et al. Case of chronic-phase chronic myelogenous leukemia with an abdominal hematopoietic tumor of leukemic clone origin. Am J Hematol. 2004;77(2):167-170.

12. Creagh TM, Bain BJ, Evans DJ, et al. Endometrial extramedullary haemopoiesis. J Pathol. 1995;176(1):99-104.

13. Freeman RK, Howden FM, Gable PS, et al. Extramedullary hematopoiesis presenting as an intraatrial mass in a patient with chronic myelogenous leukemia. J Thorac Cardiovasc Surg. 1995;110(2):552-554.

14. Shih LY, Lin FC, Kuo TT. Cutaneous and pericardial extramedullary hematopoiesis with cardiac tamponade in chronic myeloid leukemia. Am J Clin Pathol. 1988;89(5):693-697.

15. Martoïa R, Lamy T, Delmaire P, et al. Occurrence of non-Hodgkin's lymphoma in chronic myeloid leukemia. Rev Med Interne. 1987;8(5): 471-474.

16. Rodler E, Welborn J, Hatcher S, et al. Blastic mantle cell lymphoma developing concurrently in a patient with chronic myelogenous leukemia and a review of the literature. Am J Hematol. 2004;75(4): 231-238.

17. Liu Z, Liu C, Guo W, et al. Clinical analysis of 152 cases of multiple primary malignant tumors in 15,398 patients with malignant tumors. PLoS One. 2015;10(5):e0125754.
Therapeutics and Clinical Risk Management

\section{Publish your work in this journal}

Therapeutics and Clinical Risk Management is an international, peerreviewed journal of clinical therapeutics and risk management, focusing on concise rapid reporting of clinical studies in all therapeutic areas, outcomes, safety, and programs for the effective, safe, and sustained use of medicines. This journal is indexed on PubMed Central, CAS,

\section{Dovepress}

EMBase, Scopus and the Elsevier Bibliographic databases. The manuscript management system is completely online and includes a very quick and fair peer-review system, which is all easy to use. Visit http://www.dovepress.com/testimonials.php to read real quotes from published authors. 